\title{
Synthesis of (2S,3R)-3-amino-2-hydroxydecanoic acid and its enantiomer: a non-proteinogenic amino acid segment of the linear pentapeptide microginin
}

\author{
Rajendra S. Rohokale and Dilip D. Dhavale*
}

\author{
Full Research Paper \\ Address: \\ Department of Chemistry, Garware Research Centre, University of \\ Pune, Pune - 411 007, India

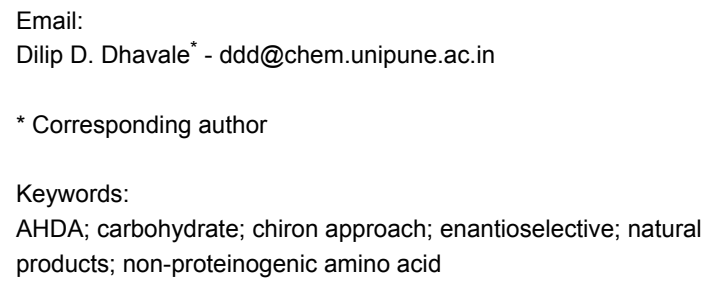

Beilstein J. Org. Chem. 2014, 10, 667-671.

doi:10.3762/bjoc. 10.59

Received: 19 November 2013

Accepted: 10 February 2014

Published: 17 March 2014

This article is part of the Thematic Series "Natural products in synthesis and biosynthesis".

Guest Editor: J. S. Dickschat

(C) 2014 Rohokale and Dhavale; licensee Beilstein-Institut.

License and terms: see end of document.

\begin{abstract}
A directed manipulation of the functional groups at $\mathrm{C} 3$ and $\mathrm{C} 4$ of D-glucose was demonstrated to synthesize naturally occurring $(2 S, 3 R)$ - $\alpha$-hydroxy- $\beta$-aminodecanoic acid (AHDA, 2a) and its enantiomer $\mathbf{2} \mathbf{b}$. The enantiomer of $\mathbf{2 a}$ is the $\mathrm{N}$-terminal part of the natural linear pentapeptide microginin, which is used as an antihypertensive agent.
\end{abstract}

\section{Introduction}

Microginin 1 (Figure 1), isolated from the cyanobacterium Microcystis aeruginosa, is a linear pentapeptide consisting of L-Tyr-L- $N$-Me-Tyr-L-Val-L-Ala and $(2 S, 3 R)$ - $\alpha$-hydroxy- $\beta$ aminodecanoic acid $((2 S, 3 R)$-AHDA, 2a) [1]. Microginin is used as a hypertensive agent based on its biological activity against angiotensin converting enzyme, which is responsible for the vasoconstriction of blood vessels [2-4]. Amongst different amino acids present in microginin, $(2 S, 3 R)$-AHDA (2a) is a non-proteinogenic natural amino acid attached at the $\mathrm{N}$-terminal part of the peptide chain. The $\alpha$-hydroxy- $\beta$-amino acid fragment in AHDA 2a is also present in linear peptides such as bestatin and valinoctin [5-8], which are isolated from the same species. In addition, the chiral $\alpha$-hydroxy- $\beta$-amino acid constituent is an important component of protein kinase inhibitor compounds like balanol and the anticancer drug taxol [9].

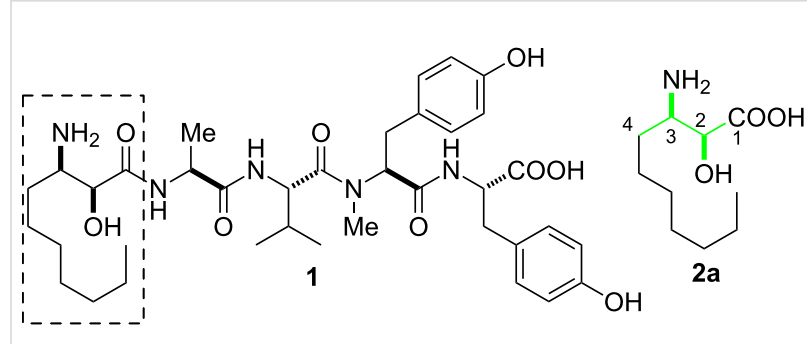

Figure 1: Microginin (1) and (2S,3R)-AHDA (2a). 
Due to the biological importance of $(2 S, 3 R)$-AHDA, the enantioselective synthesis of its chiral core is a challenge task. This fact led to several approaches for the stereoselective synthesis of $(2 S, 3 R)$-AHDA including (i) the enantioselective introduction of amino- and hydroxy-groups to olefinic acid by either asymmetric epoxidation, dihydroxylation or aminohydroxylation [10-15], (ii) the asymmetric synthesis of $\beta$-lactams by a Staudinger reaction between ketene and imine to give the corresponding amino acids [16], and (iii) the Lewis acid catalyzed multicomponent condensation reactions of aldehyde, an amine and ketene silyl acetal derivatives to get the vicinal hydroxylamino acids [17]. In addition, a few strategies employ a chiral pool approach. For example, Wee et al. utilized the zinc-silver-mediated reductive elimination of $\alpha$-D-lyxofuranosyl phenylsulfone to get $(4 S, 5 S)$-4-formyl-5-vinyl-2-oxazolidone, which was converted into 2a [18]. Merrer and co-workers used D-isoascorbic acid, which was transformed via $(2 R)$ amino-1,3,4-triol to 2a [19]. Bergmeier et al. synthesized a chiral allyl alcohol from D-mannitol, which is converted to the azidoformate and thermally cyclized to a bicyclic aziridine. The opening of the aziridine with organocuprate led to a corresponding chiral hydroxylated amino acid core [20]. Although a number of chiron approaches are known [21], there is no report from D-glucose towards the synthesis of $(2 S, 3 R)$-AHDA (2a) and its enantiomer $(2 R, 3 S)$-AHDA (2b). As a part of our continuous interest in the synthesis of chiral amino acids [22,23] and their utility in the synthesis of iminosugars [24-29], we report here an efficient and practical approach for the synthesis of both enantiomers of AHDA (2a and $\mathbf{2 b}$ ) from the same precursor D-glucose by simple manipulation of the functional groups.

We visualized that the structural and the stereochemical symmetry of both enantiomers $(\mathbf{2} \mathbf{a} / \mathbf{2} \mathbf{b})$ is present in D-glucose. The C1-carboxyl carbon atom of $\mathbf{2 a}$ is present at the $\mathrm{C} 2$ of the D-glucose, and the $\mathrm{C} 4$ carbon atom with an alkyl chain in $\mathbf{2 a}$ could be built on $\mathrm{C} 5$ of the D-glucose (Scheme 1). The required relative stereochemistry of the vicinal hydroxyamino function- ality in $2 a$ at $\mathrm{C} 2$ and $\mathrm{C} 3$ is embedded at the $\mathrm{C} 3$ and $\mathrm{C} 4$ of D-glucose, respectively, and needs to be manipulated by usual functional group transformations. Thus, for the synthesis of enantiomers $\mathbf{2} \mathbf{a}$ and $\mathbf{2} \mathbf{b}$ the corresponding sugar precursors were found to be suitably protected $\beta$-L-arabino-pentodialdo-1,4furanose 3a [30,31] and $\alpha$-D-ribo-pentodialdo-1,4-furanose $\mathbf{3 b}$ [32]. There exists a distinct possibility to synthesize these chiron synthons $\mathbf{3 a}$ and $\mathbf{3 b}$ from the easily available and cheap starting material D-glucose. Our results of the synthesis of both enantiomers $\mathbf{2} \mathbf{a}$ and $\mathbf{2} \mathbf{b}$ are described herein.

\section{Results and Discussion}

As reported earlier, D-glucose was converted to the 3-O-benzyl1,2- $O$-isopropylidene- $\beta$-L-arabino-pentodialdo-1,4-furanose (3a) in $72 \%$ yield (Scheme 2) [30]. While targeting the synthesis of $\mathbf{2 a}$, the Wittig olefination of $\mathbf{3 a}$ with $n$-hexyltriphenylphosphonium bromide and $t$-BuOK gave olefin $4 \mathbf{a}$ as a diasteromeric mixture of $Z$ and $E$-isomers in the ratio 9.5:0.5 as shown by ${ }^{1} \mathrm{H}$ NMR of the crude product. The catalytic hydrogenation of alkene $4 \mathrm{a}$ with $10 \% \mathrm{Pd} / \mathrm{C}$ in methanol:ethyl acetate (3:2) at balloon pressure gave 4-heptyl-L-threose derivative 5a as a viscous oil in $99 \%$ yield [33]. Removal of the 1,2-acetonide group with TFA-water in 5a provided an anomeric mixture of the hemiacetal, which was directly subjected to oxidative cleavage by using sodium metaperiodate in acetone-water (to cleave the anomeric carbon) followed by a treatment with sodium borohydride to give triol $\mathbf{6 a}$ as a viscous oil in $78 \%$ overall yield in three steps [34]. The primary hydroxy group of triol 6a was selectively monosilylated with $t$-butyldiphenylsilyl chloride to give 7a. Subsequently, the secondary hydroxy group in 7a was converted to azido derivative 8a with an inversion of the configuration by using diphenylphosphoryl azide in the presence of DBU in $88 \%$ yield [35]. Cleavage of the silyl functionality in 8a with $n$-tetrabutylammonium fluoride offered azido alcohol 9a as a viscous oil. The azido alcohol 9a was oxidized to the corresponding acid by using $\mathrm{RuCl}_{3} \cdot 3 \mathrm{H}_{2} \mathrm{O} / \mathrm{NaIO}_{4}$ to give 10a [36].
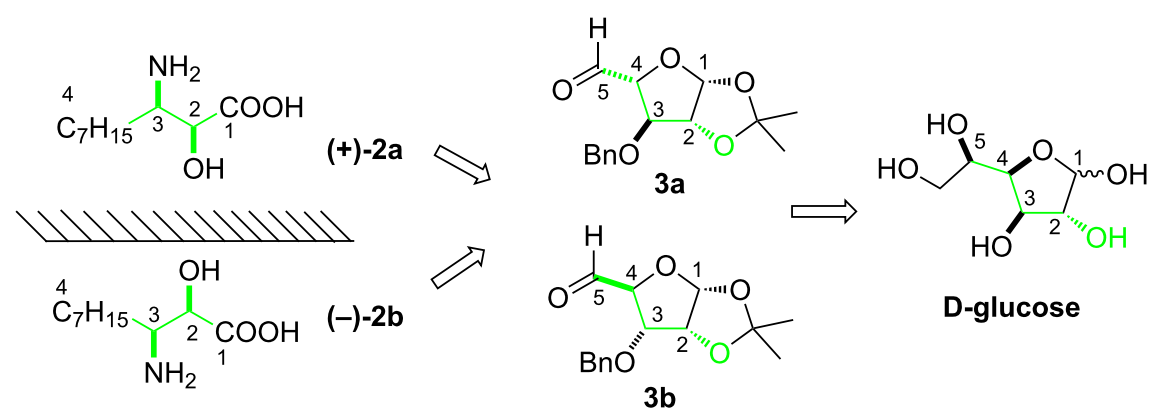


$$
\begin{aligned}
& \text { D-glucose } \stackrel{\text { ref [30] }}{\longrightarrow} \underset{3 a}{\text { (i) }}
\end{aligned}
$$

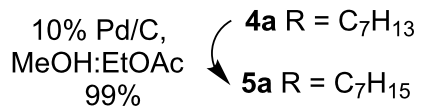

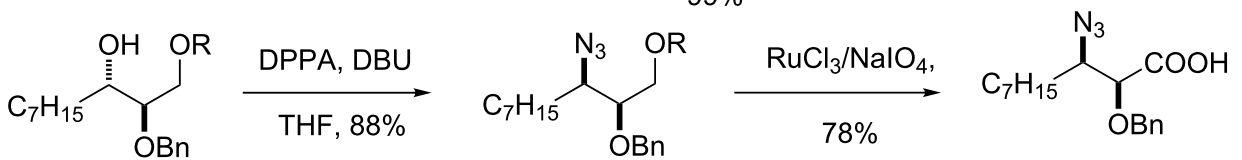

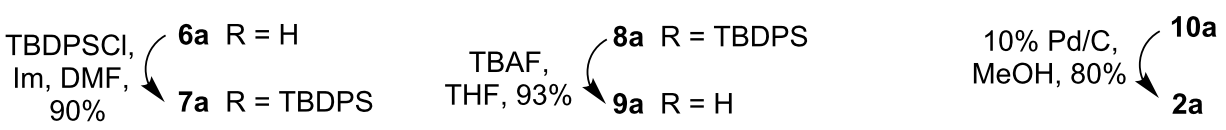

Scheme 2: Synthesis of AHDA 2a.

Finally, cleavage of the 2-O-benzyl ether and reduction of the 3 -azido group to the corresponding amine in one step with $10 \%$ $\mathrm{Pd} / \mathrm{C}$ in methanol provided (-)- $\alpha$-hydroxy- $\beta$-aminodecanoic acid (AHDA, 2a) in $80 \%$ yield as a white solid. The spectral and analytical data of $\mathbf{2 a}$ was found to be in good agreement with published data $\left([\alpha]_{\mathrm{D}}{ }^{25}+5.6(c 0.51,1 \mathrm{M} \mathrm{HCl}) \cdot[\alpha]_{\mathrm{D}}{ }^{22}+7.3\right.$ (c $0.37,1 \mathrm{M} \mathrm{HCl}))$ [18].

The synthesis of AHDA enantiomer $\mathbf{2 b}$ was accomplished starting from 3-O-benzyl-1,2- $O$-isopropylidene- $\alpha$-D-ribo-pentodialdo-1,4-furanose (3b) which was obtained from D-glucose in good yield as reported earlier [33]. Thus, the Wittig reaction of 3b followed by hydrogenation $(10 \% \mathrm{Pd} / \mathrm{C})$ gave 4-heptyl-Dthreose derivative $\mathbf{5 b}$ (Scheme 3 ). Hydrolysis of 1,2-Oisopropylidene (TFA: $\mathrm{H}_{2} \mathrm{O}$ ) followed by oxidative cleavage of the hemiacetal with $\mathrm{NaIO}_{4}$ and reduction with $\mathrm{NaBH}_{4}$ gave triol $\mathbf{6 b}$,which was monosilylated with TBDPSCl to give $\mathbf{7 b}$. Conversion of the secondary hydroxy group in $\mathbf{7 b}$ to azide $\mathbf{8 b}$ according to the Mitsunobu protocol, and deprotection followed by oxidation of the primary hydroxy group gave azido acid 10b. Finally, hydrogenolysis of the benzyl group and reduction of the azido group by using $10 \% \mathrm{Pd} / \mathrm{C}$, in one pot, gave $\mathbf{2 b}$ in $30.1 \%$ overall yield from $\mathbf{3 b}$. The spectral and analytical data was found to be in good agreement with reported data $\left([\alpha]_{\mathrm{D}}{ }^{30}-5.1(c 0.51,1 \mathrm{M} \mathrm{HCl}) .[\alpha]_{\mathrm{D}}{ }^{30}-6.2(c 0.4,1 \mathrm{M}\right.$ $\mathrm{HCl}))[21]$.

\section{Conclusion}

In conclusion, we demonstrated a practical approach for the synthesis of both enantiomers of AHDA (2a and $\mathbf{2 b}$ ) to obtain the stereochemistry required for the $\alpha$-hydroxy- $\beta$-amino acid. Our method starts from D-glucose by an easy manipulation of

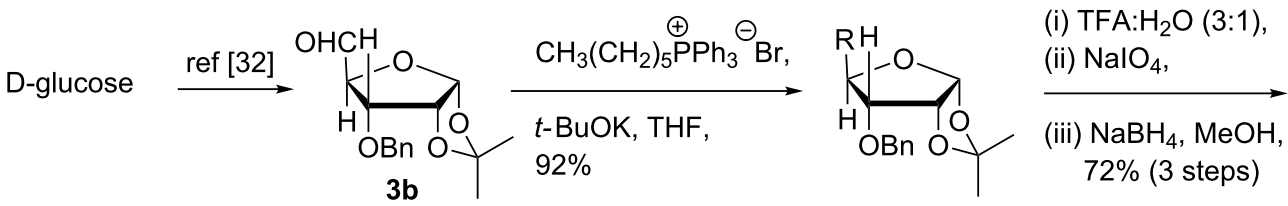

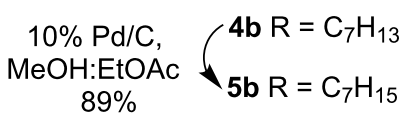

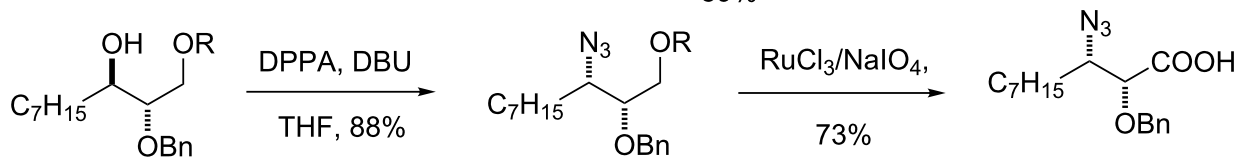

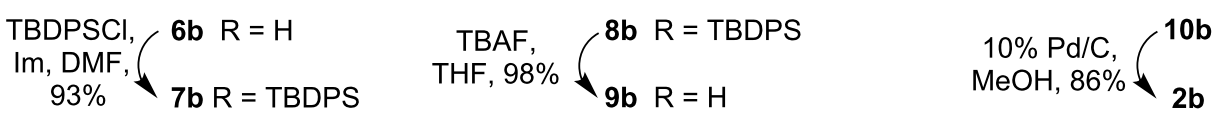


its functional groups at $\mathrm{C} 3$ and $\mathrm{C} 4$. In addition, the chiral core ( $\alpha$-hydroxy- $\beta$-amino acid) in $\mathbf{2 a}$ is present in several biologically active compounds such as taxol, balanol and bestatin. Therefore, this methodology could be potentially exploited for the synthesis of the chiral segment of these compounds.

\section{Supporting Information}

\section{Supporting Information File 1}

Experimental procedures.

[http://www.beilstein-journals.org/bjoc/content/

supplementary/1860-5397-10-59-S1.pdf]

\section{Supporting Information File 2}

Copies of NMR spectra.

[http://www.beilstein-journals.org/bjoc/content/

supplementary/1860-5397-10-59-S2.pdf]

\section{Acknowledgements}

We are thankful to the Department of Science and Technology, New Delhi (Project File No. SR/S1/OC-20/2010) for providing financial support. R.S.R. is thankful to CSIR, New Delhi for providing a Junior Research Fellowship.

\section{References}

1. Okino, T.; Matsuda, H.; Murakami, M.; Yamaguchi, K. Tetrahedron Lett. 1993, 34, 501-504. doi:10.1016/0040-4039(93)85112-A

2. Wyvratt, M. J.; Patchett, A. A. Med. Res. Rev. 1985, 5, 483-531. doi:10.1002/med.2610050405

3. Moore, R. E.; Banarjee, S.; Bomemann, V.; Caplan, F. R.; Chen, J. L.; Corley, D. G.; Larsen, L. K.; Moore, B. S.; Patterson, G. M. L.; Paul, V. J.; Stewart, J. B.; Williams, D. E. Pure Appl. Chem. 1989, 61, 521-524. doi:10.1351/pac198961030521

4. Carmichael W. W. Handbook of Natural Toxins; Tu, A. T.; Ed.; Marcel Dekker: New York, 1988; pp. $121 \mathrm{ff}$.

5. Umezawa, H.; Aoyagi, T.; Suda, H.; Hamada, M.; Takeuchi, T. J. Antibiot. 1976, 29, 97-99. doi:10.7164/antibiotics.29.97

6. Nakamura, H.; Suda, H.; Takita, T.; Aoyagi, T.; Umezawa, H. J. Antibiot. 1976, 29, 102-103. doi:10.7164/antibiotics.29.102

7. Sekizawa, R.; linuma, H.; Muraoka, Y.; Naganawa, H.; Kinoshita, N.; Nakamura, H.; Hamada, M.; Takeuchi, T.; Umezawa, K. J. Nat. Prod. 1996, 59, 232-236. doi:10.1021/np960067t

8. Tsuda, M.; Muraoka, Y.; Takeuchi, T. J. Antibiot. 1996, 49, 1031-1035. doi:10.7164/antibiotics.49.1031

9. Nicolau, K. C.; Dai, W.-M.; Guy, R. K. Angew. Chem., Int. Ed. 1994, 33, 15-44. doi:10.1002/anie.199400151

10. Bunnage, M. E.; Burke, A. J.; Davies, S. G.; Goodwin, C. J. Tetrahedron: Asymmetry 1994, 5, 203-206. doi:10.1016/S0957-4166(00)86173-X

11. Li, G.; Chang, H.-T.; Sharpless, K. B. Angew. Chem., Int. Ed. 1996, 35 , 451-454. doi:10.1002/anie.199604511

12. Chandrasekhar, S.; Mohapatra, S.; Yadav, J. S. Tetrahedron 1997, 8 , 4089-4099. doi:10.1016/S0957-4166(97)00595-8
13. Sugimura, H.; Miura, M.; Yamada, N. Tetrahedron: Asymmetry 1997, 8 , 4089-4099. doi:10.1016/S0957-4166(97)00595-8

14. Righi, G.; Chionne, A.; D’Achille, R.; Bonini, C. Tetrahedron: Asymmetry 1997, 8, 903-907. doi:10.1016/S0957-4166(97)00056-6

15. Jeffords, C. W.; Mcnulty, J.; Lu, Z. H.; Wang, J. B. Helv. Chim. Acta 1996, 79, 1203-1216. doi:10.1002/hlca.19960790426

16. Ha, H. J.; Ahn, Y. G.; Woo, J. S.; Lee, G. S.; Lee, W. K. Bull. Chem. Soc. Jpn. 2001, 74, 1667-1672. doi:10.1246/bcsj.74.1667

17. Gassa, F.; Contini, A.; Fontana, G.; Pellegrino, S.; Gelmi, M. L. J. Org. Chem. 2010, 75, 7099-7106. doi:10.1021/jo1011762

18. Wee, A. G. H.; McLeod, D. D. J. Org. Chem. 2003, 68, 6268-6273. doi:10.1021/jo034334t

19. Tuch, A.; Saniere, M.; Merrer, Y. L.; Depezay, J.-C. Tetrahedron: Asymmetry 1996, 7, 2901-2909. doi:10.1016/0957-4166(96)00381-3

20. Bergmeier, S. C.; Stanchina, D. M. J. Org. Chem. 1999, 64, 2852-2859. doi:10.1021/jo9823893

21. Shirode, N. M.; Deshmukh, A. R. A. S. Tetrahedron 2006, 62, 4615-4621. doi:10.1016/j.tet.2006.01.082

22. Kalamkar, N. B.; Kasture, V. M.; Dhavale, D. D. Tetrahedron Lett. 2010, 51, 6745-6747. doi:10.1016/j.tetlet.2010.10.086

23. Kalamkar, N. B.; Kasture, V. M.; Dhavale, D. D. J. Org. Chem. 2008, 73, 3619-3622. doi:10.1021/jo702749r

24. Dhavale, D. D.; Markad, S. D.; Karanjule, N. S.; Prakasha Reddy, J. J. Org. Chem. 2004, 69, 4760-4766. doi:10.1021/jo049509t

25. Karanjule, N. S.; Markad, S. D.; Dhavale, D. D. J. Org. Chem. 2006, 71, 6273-6276. doi:10.1021/jo060823s

26. Karanjule, N. S.; Markad, S. D.; Shinde, V. S.; Dhavale, D. D. J. Org. Chem. 2006, 71, 4667-4670. doi:10.1021/jo0601617

27. Dhavale, D. D.; Ajish Kumar, K. S.; Chaudhari, V. D.; Sharma, T.; Sabharwal, S. G.; Prakasha, R. Org. Biomol. Chem. 2005, 3, 3720-3726. doi:10.1039/b509216g

28. Ajish Kumar, K. S.; Chaudhari, V. D.; Puranik, V. G.; Dhavale, D. D. Eur. J. Org. Chem. 2007, 4895-4901. doi:10.1002/ejoc.200700461

29. Pawar, N. J.; Parihar, V.; Chavan, S.; Joshi, R.; Joshi, P. V.; Sabharwal, S. G.; Puranik, V. G.; Dhavale, D. D. J. Org. Chem. 2012, 77, 7873-7882. doi:10.1021/jo3009534

30. Sato, K.-i.; Akai, S.; Sakuma, M.; Kojima, M.; Suzuki, K.-j. Tetrahedron Lett. 2003, 44, 4903-4907. doi:10.1016/S0040-4039(03)01098-0

31. Hanessian, S. Total Synthesis of Natural Products: The "Chiron" Approach; Pergamon Press: Oxford, 1983.

32. Patil, N. T.; John, S.; Sabharwal, S. G.; Dhavale, D. D. Bioorg. Med. Chem. 2002, 10, 2155-2160. doi:10.1016/S0968-0896(02)00073-1

33. Bindra, J.; Grodski, A. J. Org. Chem. 1978, 43, 3240. doi:10.1021/jo00410a031

34. Mane, R. S.; Ajish Kumar, K. S.; Dhavale, D. D. J. Org. Chem. 2008, 73, 3284-3287. doi:10.1021/jo800044r

35. Thompson, A. S.; Humphrey, G. R.; DeMarco, A. M.; Marthe, D. J.; Grabowaski, E. J. J. J. Org. Chem. 1993, 58, 5886-5888. doi:10.1021/jo00074a008

36. Carlsen, P. J. H.; Katsuki, T.; Martin, V. S.; Sharpless, K. B. J. Org. Chem. 1981, 46, 3936-3938. doi:10.1021/jo00332a045 


\section{License and Terms}

This is an Open Access article under the terms of the Creative Commons Attribution License

(http://creativecommons.org/licenses/by/2.0), which permits unrestricted use, distribution, and reproduction in any medium, provided the original work is properly cited.

The license is subject to the Beilstein Journal of Organic Chemistry terms and conditions:

(http://www.beilstein-journals.org/bjoc)

The definitive version of this article is the electronic one which can be found at:

doi:10.3762/bjoc. 10.59 